\title{
A PILOT-SCALE STUDY FOR EVALUATING THE PERFORMANCE OF A FAN-PAD COOLING SYSTEM UNDER DIFFERENT CLIMATIC CONDITIONS OF SAUDI ARABIA
}

\author{
Ibrahim M. Al-Helal
}

\begin{abstract}
In the present study, a special test setup was designed to evaluate the performance of a fan-pad evaporative cooling system under different climatic conditions in Saudi Arabia. Weather data for Riyadh representing arid climate, Jeddah representing humid climate and Abha representing moderate climate were analyzed. These data contained hourly readings for air temperature, relative humidity and solar radiation. An evaporative cooler consisting of a $10 \mathrm{~cm}$ thick cooling pad, suction fan and water pump was used. The cooling pad was installed in a $1080 \mathrm{~mm}$ high, horizontal duct of square cross-section insulated by $50 \mathrm{~mm}$ polyurethane. The duct cross-section measures $1000 \mathrm{~mm} \times 1000 \mathrm{~mm}$. A variable speed suction fan was fitted at one end and the pad was designed so that the inlet air passed through the wetted pads. Air temperature and relative humidity of the inlet air were changed to simulate dry, humid and moderate climatic conditions of Saudi Arabia. The inlet air was heated by two types of electrical heater. The heaters were fixed in a contractioncone-profile that is mounted in the air duct. The inlet air temperature was controlled by a PID temperature controller. Electrical high pressure steam boiler was used to produce low pressure steam for heating and humidifying the inlet air stream. The boiler capacity is $57 \mathrm{~kg} / \mathrm{h}$ steam at a pressure of 5.5 bar.

The weather data analyses showed that cooling of agricultural structures in Riyadh and Jeddah is very essential. The mean monthly temperature during summer in Riyadh area varies between $31.5^{\circ} \mathrm{C}$ and $36^{\circ} \mathrm{C}$, and the relative humidity is between $14.4 \%$ and $20 \%$. These conditions encourage the use of evaporative cooling.

Department of Ag. Eng., College of Food and Agriculture Sciences, King Saud University, P.O. Box 2460, Riyadh 11451, Kingdom of Saudi Arabia
\end{abstract}


In Jeddah, the mean monthly temperatures during summer vary between $30^{\circ} \mathrm{C}$ and $33.5^{\circ} \mathrm{C}$, and the relative humidity is between $57 \%$ and $82 \%$. Cooling of agricultural structures in Abha is not necessary, except greenhouses that act as solar collectors. The mean monthly temperatures in Abha during summer vary between $22^{\circ} \mathrm{C}$ and $23.5^{\circ} \mathrm{C}$, and the relative humidity was between $35 \%$ and $70 \%$.

Averages of monthly solar radiation levels during summer vary between 570 and $619 \mathrm{~W} / \mathrm{m}^{2}$, for Riyadh, between 503 and $580 \mathrm{~W} / \mathrm{m}^{2}$, for Jeddah, and between 477 and $591 \mathrm{~W} / \mathrm{m}^{2}$, for Abha. Experimental results showed that averages of cooling efficiency were $82.4 \%, 72.2 \%$ and $75 \%$ under arid, humid and moderate conditions, respectively.

The highest air temperature drop through the pad was observed under arid dry conditions with a range of $12-32.5^{\circ} \mathrm{C}$. Whereas air temperature drop was lowest under humid hot conditions with a range of $2.8-8.6^{\circ} \mathrm{C}$. The drop under moderate conditions ranged from 6 to $15.3^{\circ} \mathrm{C}$. The maximum cooling of $20612 \mathrm{~W}$ was obtained for the arid climatic conditions compared to $11883 \mathrm{~W}$ and $5992 \mathrm{~W}$ for moderate and humid climatic conditions, respectively. Cooling water consumption rate increased by increasing both temperature of the inlet air and air speed through the pads. The consumption rates were 11.8 and $13.8 \mathrm{l} / \mathrm{hr}$ at inlet air temperatures of 40 and $45^{\circ} \mathrm{C}$, respectively, when air speed was 0.5 $\mathrm{m} / \mathrm{s}$. The rate increased from $8.8 \mathrm{l} / \mathrm{hr}$ at air speed of $0.25 \mathrm{~m} / \mathrm{s}$ to $19.8 \mathrm{l} / \mathrm{hr}$ at air speed of $1 \mathrm{~m} / \mathrm{s}$ when the air temperature at the inlet was $40^{\circ} \mathrm{C}$. The water consumption decreased as the relative humidity of the inlet air increased at the same temperature. The water consumption rate decreased from $13.8 \mathrm{l} / \mathrm{hr}$ to $5.8 \mathrm{l} / \mathrm{hr}$ by increasing relative humidity from $8 \%$ to $58 \%$, respectively, at inlet air temperature of $35^{\circ} \mathrm{C}$.

\section{INTRODUCTION}

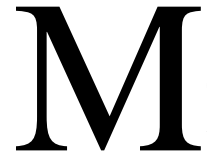

ost regions in the Kingdom of Saudi Arabia have harsh environment for plant and animal production. In addition to water deficiency, the ambient temperature and relative humidity are not suitable for commercially produced plants and animals. Therefore, it is essential to cool agricultural structures by either evaporative cooling or refrigeration air conditioning that has high initial 
cost and demand high input of power. Evaporative cooling systems are commonly used for cooling of agricultural structures in Saudi Arabia with comparatively low investment and less power input. Evaporative cooling has been reported for achieving a favorable environment for greenhouses crops (Montero et al. 1981; Kittas et al., 2001); poultry and dairy houses for reducing heat stress on animals (Gates et al., 1991; Bottcher et al., 1991; Ryan et al., 1992; Ali et al., 1999; Arbel et al., 1999; Zabeltitz, 2002; and Chen, 2003) and storage structure for fruits and vegetables (Helson and Wilmot, 1991 and Umbarker et al., 1991). Kittas et al. (2001) observed that a fan-pad cooling system during summer in a commercial greenhouse producing cut roses and a half-shaded plastic roof reached $80 \%$ efficiency and succeeded in maintaining greenhouse temperatures that were cooler (up to $10^{\circ} \mathrm{C}$ lower) than outside. It has been reported by several researchers that evaporative cooling improved milk production and fertility for cows during summertime climates (El-Nouty et al., 1990; Bucklin et al., 1991 and Ali et al., 1999). Also, use of evaporative cooling minimized the heat stress birds were exposed to during growth period (Deaton et al., 1982; and Reece et al., 1972).

Fans combined with wetted pads are the most widely used for greenhouses cooling (Montero et al. 1981; Jain and Tiwari, 2002). Evaporative cooling effectiveness depends upon several factors including width and density of pads and pad material used (Watt, 1953; Wiersma and Benham, 1974; Al-Helal and Al-Towejeri, 2001; Liao and Chiu, 2002). Increasing pads width increases resistance to air flow and airwater contact area, and minimize water evaporation rate as the air moves through the pads. Different pad materials are being used such as aspen pads, corrugated cellulose, plastic fibers and palm dates fibers. Generally, the pads width ranged between 5 to $10 \mathrm{~cm}$ for the aspen pads, and between 10 to $15 \mathrm{~cm}$ for the corrugated cellulose. Watt (1953) indicated that the optimum density for the vertical aspen pad is $32 \mathrm{~kg} / \mathrm{m}^{3}$. Increasing pads density would increase resistance to air flow. Also, the face velocity of the air affects the contact between air and water, and high velocity of air carry-over of water droplets from the cooling pad to the interior. The recommended face velocities through the corrugated 
cellulose pad with thickness of 10 and $15 \mathrm{~cm}$ are 1.25 and $1.75 \mathrm{~m} / \mathrm{s}$, respectively (ASAE, 2000).

Al-Helal and Al-Towejeri (2001) studied evaporative cooling efficiencies for palm dates fiber pad and cross-fluted cellulose pad were studied under arid conditions. Experiments were carried out during noon hours were averages of outside dry-bulb temperature and relative humidity were $44^{\circ} \mathrm{C}$ and $14.5 \%$, respectively. The highest cooling efficiencies for crossfluted cellulose pad and palm dates fiber pad $(77 \%$ and $69 \%$, respectively) was obtained with a thickness of $10 \mathrm{~cm}$ and a water addition rate of $11 \mathrm{l} / \mathrm{min}$. The lowest cooling efficiency for cross-fluted cellulose pads $(53 \%)$ was obtained when thickness and water addition rate were 5 $\mathrm{cm}$ and $3 \mathrm{l} / \mathrm{s}$, respectively. The lowest cooling efficiency for palm dates fiber pad $(47 \%)$ was obtained when thickness and water addition rate were $10 \mathrm{~cm}$ and $3 \mathrm{l} / \mathrm{s}$, respectively.

Liao and Chiu (2002) developed a compact wind tunnel to investigate evaporative cooling pad-fan system performance in Taiwan region. Two alternative materials including one made of coarse fabric PVC sponge mesh $2.5 \mathrm{~mm}$ diameter in pinhole and one made of fine fabric PVC sponge mesh in $7.5 \mathrm{~mm}$ diameter pinhole were tested as pads. The effects of air velocity, water flow rate, static pressure drop across pad, and pad thickness on evaporative cooling efficiency were examined. Cooling efficiencies for coarse fabric PVC sponge ranged from 63.88 to $64.77 \%$, 80.50 to $81.68 \%$, and 81.75 to $86.32 \%$, respectively, for 5,10 , and $15 \mathrm{~cm}$ thickness under normal operating air velocities of $1.0-1.5 \mathrm{~m} / \mathrm{s}$. Cooling efficiencies for fine fabric PVC sponge ranged from 47.22 to $57.23 \%$, 62.93 to $72.25 \%$, and 76.68 to $85.51 \%$ for 5,10 , and $15 \mathrm{~cm}$ thickness, respectively, under normal operating air velocities.

Limited data are available on the fan-pad evaporative cooling performance under climatic conditions of Saudi Arabia. One study evaluating the performance of three natural fibers to be used as wetted pads in evaporative cooling; date palm fibers (stem), jute and luffa was the study of Al-Sulaiman (2002). The average cooling efficiency was highest for jute at $62.1 \%$, compared to $55.1 \%$ for luffa fibers, $49.9 \%$ for the reference commercial pad and $38.9 \%$ for date palm fiber. Alodan and Al-Faraj (2005) evaluated a new alternative cooling pads made from 
galvanized metal sheets under arid conditions of Riyadh. The cooling efficiency ranged from $73 \%$ to $89 \%$ depending on the pads depth. AlHelal et al., (2004) investigated the cooling efficiency for a fan-pad system for a photovoltaic powered greenhouse under extreme summer conditions of central regions of Saudi Arabia. The cooling efficiency averaged at $71 \%$, with 8 to $17.3^{\circ} \mathrm{C}$ reductions in ambient temperature.

The present study evaluated the performance of evaporative cooling in regions with arid, humid and moderate climates. Evaluation of the fan-pad system under different weather conditions requires an analysis of weather data such as air temperature, solar radiation and relative humidity. All are especially important factors for the evaporative cooling efficiency and drybulb temperature drop for the cooled air. The data was also used for defining weather characteristics during summer, deciding the need of air cooling before it enters any agricultural structures and determining the time of the day where the cooling load can reach its maximum level (peak). Because of the difficulties in field measurements, a pilot-scale study in the environmental control laboratory was performed to quantify system performance under controlled conditions.

\section{MATERIALS AND METHODS}

\section{Procedure and instrumentation}

This study was carried out in the environmental control laboratory, department of agricultural engineering at the college of food and agricultural sciences, King Saud University. An evaporative cooler consisting of a $10 \mathrm{~cm}$ thick Celdek cooling pad, suction fan and water pump was used. The cooling pad was installed in a $1 \mathrm{~m}$ high, horizontal duct of square cross-section. The duct was made of Varifoam, thickness of 55mm (VF-55) composite a sandwich panel, coated with Polyester with standard bone white colore, and insulated by $50 \mathrm{~mm}$ polyurethane foam insulation, $\mathrm{U}$-value of $0.49 \mathrm{~W} / \mathrm{m}^{2 \circ} \mathrm{C}$. The duct cross-section measures $1 \mathrm{~m} \times 1 \mathrm{~m}$. A variable speed suction fan (Type 8D92-3pp-21Q, Multifan, Venlo, Holland) was fitted at one end and the pad was designed so that the inlet air passed through a $10 \mathrm{~cm}$ thick, $90 \mathrm{~cm}$ by $90 \mathrm{~cm}$ cooling pad. The pad was of the cross-fluted cellulose type (Cel-dek, Munters $\left.{ }^{\circledR}\right)$. Pads were installed vertically so that the pad was wetted by distributing 
water over the pad top using a distribution pipe. The pipe was made of PVC, $25 \mathrm{~mm}$ in diameter and had $4 \mathrm{~mm}$ diameter holes drilled on $50 \mathrm{~mm}$ centers along the top of the distribution pipe. The water is forced upward, strikes a cover plate and trickles down to the pads. Water was supplied to the pad from a stainless steel sump $(800 \mathrm{~mm} \times 450 \mathrm{~mm} \times 300 \mathrm{~mm})$ that serves as a reservoir. Water was continuously supplied to the sump from a galvanized metal water tank $(1000 \mathrm{~mm} \times 500 \mathrm{~mm} \times 500 \mathrm{~mm})$ to replace evaporative and losses. It was added by having a water supply line to the sump that was controlled by a float (Figure 4). A pump (Pedrollo, Italy, $0.5 \mathrm{HP}, 380 \mathrm{~V}, 5-40 \mathrm{l} / \mathrm{min}$ ) was used to move water from the sump to the top of the pads. The water was added to the pads at a constant rate. Figure 4 shows a diagram of the components of evaporative cooling pad system.

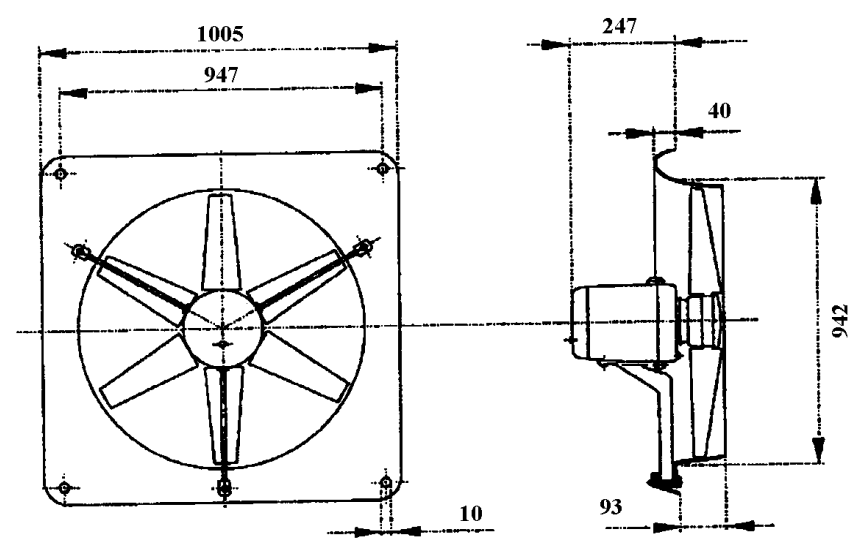

Fig. 1. Schematic illustration of the suction fan.

Air temperature and relative humidity of the inlet air were changed before passing through the cooling pads in order to simulate dry, humid and moderate climatic conditions. The inlet air was heated sensibly to increase its temperature and decrease its relative humidity by two electrical heaters. The first heater was composed of four duct heater units; each has a rated maximum capacity of $3 \mathrm{~kW}$ and a voltage of 220VAC. The second is consisted of three air fins tubular heater units, each with a rated maximum capacity of $3 \mathrm{~kW}$ and a voltage of $220 \mathrm{VAC}$. The heaters were fixed in a contraction-cone-profile that keeps a uniform air in the 
duct, while decreasing the area to a $500 \times 500 \mathrm{~mm}$ cross-section. The inlet air temperature was controlled by a PID temperature controller that displays both actual and desired air temperatures. The controller has input and output. The input was connected to a sensor for measuring temperature of the heated air, and the output was connected to a solid static relay that controls the operation of the heaters.

Electrical high pressure Electric steam boiler (ALKA Boiler, model ALKA 36E) was used to produce low pressure steam for heating and humidifying the inlet air stream. The boiler made of stainless steel, and makes steam by the heating of electric heater to generate steam within 7-8 minutes after switch-on. The boiler capacity is $57 \mathrm{~kg} / \mathrm{h}$ steam at a pressure of 5.5 bar. The steam moved through a metal pipe having a diameter of 19 $\mathrm{mm}$, and injected into the air stream inside the duct through a 9 pipes that had $3 \mathrm{~mm}$-diameter holes drilled on $50 \mathrm{~mm}$ centers. All units (cooling pads, heaters and boilers) were installed in the duct.

\section{Measurements}

Measurements included air dry bulb temperature and relative humidity in front and in rear of the pad, and air speed in rear of the pad. Air temperature and relative humidity were measured with portable humidity and temperature sensors (DME 701, LSI, Italy). The air speed was measured using hot wire probe (DNE506, LSI, Italy). The signals were connected to computer (Dell, Optiplex Gx270, Pentium 4, $2.8 \mathrm{GHz}, 8 \mathrm{~GB}$, $512 \mathrm{MB}$ ) by using data acquisition system type PCI-6229M and analyzed by LabView program from National Instrument. Data was collected each 10s by a data logger (LI-COR-1400) and averaged over a time of $1 \mathrm{~min}$. The water consumption rate due to evaporation effect was measured by measuring water level decrease in the tank during the test period. The cooling efficiency $(\eta)$ was evaluated based on the equation: 


$$
\eta=\frac{\mathrm{T}_{\text {in }}-\mathrm{T}_{\text {out }}}{\mathrm{T}_{\text {in }}-\mathrm{T}_{\mathrm{w}}} \times 100
$$

where $\mathrm{T}_{\text {in }}$ is the inlet dry-bulb temperature $\left({ }^{\circ} \mathrm{C}\right), \mathrm{T}_{\text {out }}$ is the outlet dry-bulb temperature $\left({ }^{\circ} \mathrm{C}\right)$, and $\mathrm{T}_{\mathrm{w}}$ is the thermodynamic wet-bulb temperature of the inlet air $\left({ }^{\circ} \mathrm{C}\right)$ which was found from the psychometric chart using drybulb temperature and relative humidity readings.

The cooling power $\mathrm{q}(\mathrm{W})$ was given by:

$\mathrm{q}=\mathrm{m}_{\mathrm{a}} \mathrm{C}_{\mathrm{p}}\left(\mathrm{T}_{\text {in }}-\mathrm{T}_{\text {out }}\right)$

where $m_{a}$ is the air mass flow rate $(\mathrm{kg} / \mathrm{s})$ and $C_{p}$ is the specific heat of dry air $\left(\mathrm{kJ} / \mathrm{kg}^{\circ} \mathrm{C}\right)$.

The air mass flow rate $(\mathrm{kg} / \mathrm{s})$ was determined by:

$\mathrm{m}_{\mathrm{a}}=\mathrm{V}_{\mathrm{a}} \rho$

where $\mathrm{V}_{\mathrm{a}}$ is the volumetric air flow rate $\left(\mathrm{m}^{3} / \mathrm{s}\right)$ and $\rho$ is the air density $\left(\mathrm{kg} / \mathrm{m}^{3}\right)$ which was defined by:

$$
\rho=\frac{\mathrm{P}}{\mathrm{R} \mathrm{T}}
$$

where $\mathrm{P}$ is the ambient atmospheric pressure $(\mathrm{Pa}), \mathrm{R}$ is the universal gas constant $(\mathrm{J} / \mathrm{kg} \mathrm{K})$ and $\mathrm{T}$ is the air temperature $(\mathrm{K})$.

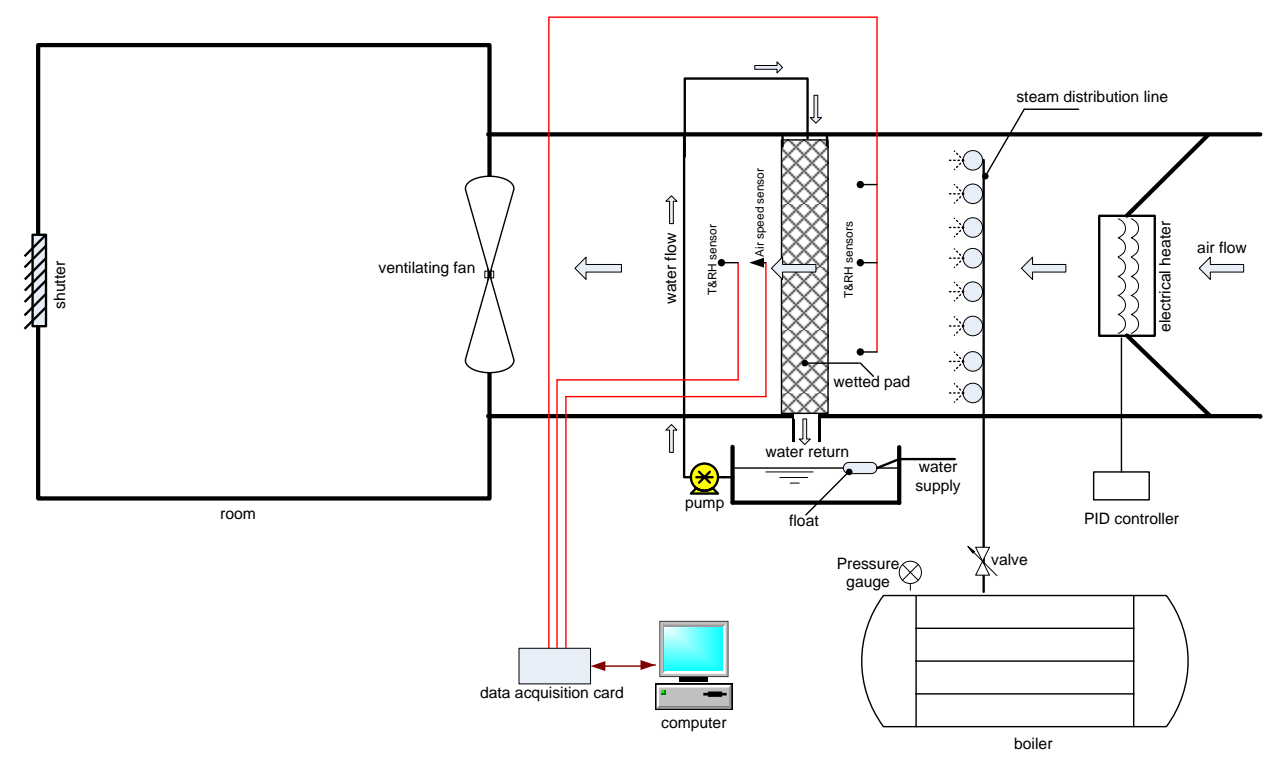

Fig. 2. Combined schematic of the evaporative cooling, heater, boiler and measurement system. 


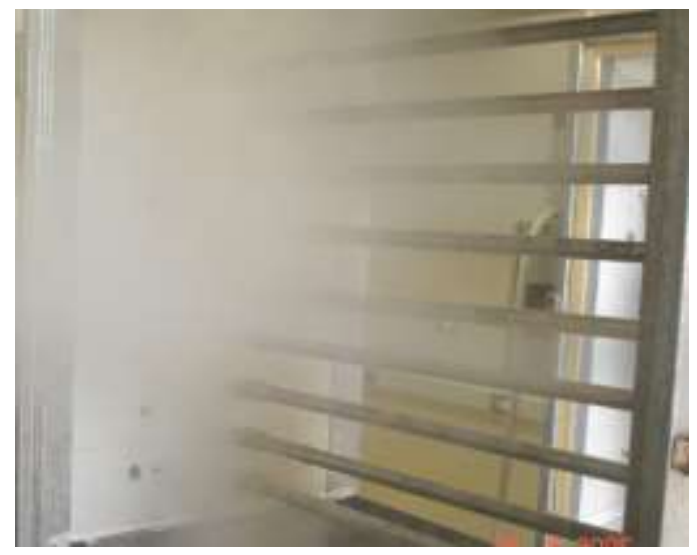

Fig. 3. Steam injection in the air duct

\section{RESULTS AND DISCUSSIONS \\ Weather characteristics}

Monthly averages of temperature, relative humidity and solar radiation for Uuaina, Jeddah and Abha are shown in table 1. It is obvious from the table that Riyadh area is characterized by arid climatic conditions (high temperature and low relative humidity) throughout summer months, i.e., during May-September. The mean monthly temperatures during this period vary between $31.5^{\circ} \mathrm{C}$ and $36^{\circ} \mathrm{C}$ during May and August, respectively, while the mean monthly relative humidity vary between $14.1 \%$ and $20 \%$ during July and May, respectively. It is under these ambient that evaporative coolers are very effective. In Jeddah, however, the hot air associated with high relative humidity lowers effectiveness of evaporative cooling. The mean monthly air temperature ranges from 30 (May) to $33.5^{\circ} \mathrm{C}$ (August), while the mean monthly relative humidity's between 57 (July) and 82\% (September). In Abha, climatic is more temperate during summer, and agricultural structures may not require the use of evaporative cooling, except greenhouse that are covered with transparent materials which allow shorter wavelength radiation (i.e. visible light) to pass through that is mostly transformed into thermal energy. This causes an accumulation of heat in the greenhouse that must be dissipated by either convective air through ventilators, or exhaust fans. The mean monthly temperatures during summer vary between $22^{\circ} \mathrm{C}$ and $23.5^{\circ} \mathrm{C}$ during May and July, respectively, while the mean monthly 
relative humidity's vary between $35 \%$ and $70 \%$ during July and August, respectively. These conditions are more favorable for crop and animal production. The mean monthly solar radiation level during summer ranges from $570 \mathrm{~W} / \mathrm{m}^{2}$ (September) to $619 \mathrm{~W} / \mathrm{m}^{2}$ (June), from $503 \mathrm{~W} / \mathrm{m}^{2}$ (September) and $580 \mathrm{~W} / \mathrm{m}^{2}$ (June), and $477 \mathrm{~W} / \mathrm{m}^{2}$ (July) and $591 \mathrm{~W} / \mathrm{m}^{2}$ (September) in Riyadh, Jeddah and Abha, respectively.

Figure 4 shows solar radiation data, temperature and relative humidity for the hottest day of the year for the three cities. The figure shows that climate in the Riyadh area is characterized by desert climatic conditions; extreme heat during summer days and abrupt drop in temperature at night. Air temperature varies between $28.5^{\circ} \mathrm{C}$ and $44.7^{\circ} \mathrm{C}$ in Riyadh, between $31^{\circ} \mathrm{C}$ and $37^{\circ} \mathrm{C}$ in Jeddah and between $19^{\circ} \mathrm{C}$ and $32.6^{\circ} \mathrm{C}$ in Abha. The figure shows that heat in Riyadh becomes intense at 8:00 a.m. and lasts until midnight. Temperature and relative humidity during this period ranged from $35.6^{\circ} \mathrm{C}$ to $44.7^{\circ} \mathrm{C}$, and from $8.3 \%$ and $14.4 \%$, respectively, while solar radiation peaked at $1032 \mathrm{~W} / \mathrm{m}^{2}$ at midday. In Jeddah, however, heat becomes intense during the period 9:00-19:00 where temperature ranged from $35^{\circ} \mathrm{C}$ to $37^{\circ} \mathrm{C}$, and relative humidity ranged from $70 \%$ to $87 \%$, while the solar radiation peaked at $1003 \mathrm{~W} / \mathrm{m}^{2}$ at midday. In Abha, heat becomes intense during the period 11:30-16:00 where air temperature ranged from $30^{\circ} \mathrm{C}$ to $32.6^{\circ} \mathrm{C}$, and relative humidity ranged from $13.1 \%$ to $35.6 \%$, while the solar radiation peaked at $1222 \mathrm{~W} / \mathrm{m}^{2}$ at 13:30.

\section{Evaporative cooling performance}

Table 2 shows the averages of air temperature, relative humidity and humidity ratio for the air leaving the cooler, cooling efficiencies, temperature reductions and cooling powers under different operating The cooling efficiencies was between $77 \%$ and $87 \%\left(\eta_{\text {avg. }}=82.4 \%\right)$ under operating arid conditions, between $65 \%$ and $84 \%\left(\eta_{\text {avg. }}=72.2 \%\right)$ under humid conditions, and between $63 \%$ and $80.5 \%$ ( $\eta_{\text {avg. }}=75 \%$ ) under moderate conditions. Also, table 2 shows that the temperature reduction was the highest under arid conditions, ranged from $12^{\circ} \mathrm{C}$ to $23.5^{\circ} \mathrm{C}$ and averaged at $18.2^{\circ} \mathrm{C}$.climatic conditions. 
Table 1. Average (standard deviation) monthly air temperatures, relative humidity and solar radiations for Riyadh, Jeddah and Abha for the year 2001.

\begin{tabular}{cllllllllc}
\hline \multirow{2}{*}{ Month } & \multicolumn{3}{c}{ Air temperature $\left({ }^{\circ} \mathrm{C}\right)$} & \multicolumn{3}{c}{ Relative humidity $(\%)$} & \multicolumn{3}{c}{ Solar radiation $\left(\mathrm{W} / \mathrm{m}^{2}\right)$} \\
\cline { 2 - 9 } & \multicolumn{1}{c}{ Riyadh } & \multicolumn{1}{c}{ Jeddah } & \multicolumn{1}{c}{ Abha } & Riyadh & \multicolumn{1}{c}{ Jeddah } & Abha & Riyadh & Jeddah & Abha \\
\hline 1 & $12.4(4.7)$ & $22.7(3.8)$ & $12(4.3)$ & $60.5(4.7)$ & $66.1(23.1)$ & $73.7(24.9)$ & 448 & 450 & 509 \\
2 & $15.2(4.6)$ & $23.1(3.7)$ & $14.8(4.2)$ & $44.8(16.1)$ & $67.2(18.5)$ & $72(24.5)$ & 475 & 447 & 531 \\
3 & $21.2(4.4)$ & $26.8(4)$ & $16.7(3.2)$ & $51.5(24.5)$ & $68.1(20.2)$ & $74(21)$ & 483 & 524 & 516 \\
4 & $26.6(4.8)$ & $20.3(4.1)$ & $19.6(4.1)$ & $27.9(13.9)$ & $66.3(19.4)$ & $61(23.5)$ & 575 & 582 & 606 \\
5 & $31.4(4.8)$ & $30.4(4.6)$ & $22(4.3)$ & $20.2(9.2)$ & $60(30.6)$ & $52(23)$ & 602 & 567 & 570 \\
6 & $33.4(4.6)$ & $31.7(4.9)$ & $23.5(2.2)$ & $14.4(4.4)$ & $60.8(25.3)$ & $35(15.8)$ & 619 & 589 & 530 \\
7 & $35.4(4.9)$ & $33.3(4.3)$ & $23.5(3.8)$ & $16.6(4.3)$ & $56.6(23.7)$ & $55(27.7)$ & 598 & 581 & 477 \\
8 & $36(4.7)$ & $33.4(2.6)$ & $22.6(4.3)$ & $19(7.1)$ & $76.5(14.9)$ & $69.7(29.3)$ & 579 & 510 & 523 \\
9 & $32.7(4.7)$ & $31.9(2.7)$ & $22.4(4.6)$ & $19.2(7.3)$ & $82.4(13.4)$ & $37.2(23.8)$ & 570 & 503 & 591 \\
10 & $27.3(4.9)$ & $30(3.7)$ & $19.3(4.3)$ & $19.6(9.7)$ & $82.4(18.1)$ & $52.9(29)$ & 451 & 494 & 564 \\
11 & $19.6(5.2)$ & $27.4(3.5)$ & $15.4(4.3)$ & $38.1(15.9)$ & $75.6(18.4)$ & $67(28)$ & 455 & 445 & 529 \\
12 & $15.6(4.8)$ & $25.6(2.9)$ & $14.8(4.3)$ & $66.9(23.3)$ & $78.8(13.5)$ & $77(23)$ & 417 & 372 & 495 \\
\hline
\end{tabular}



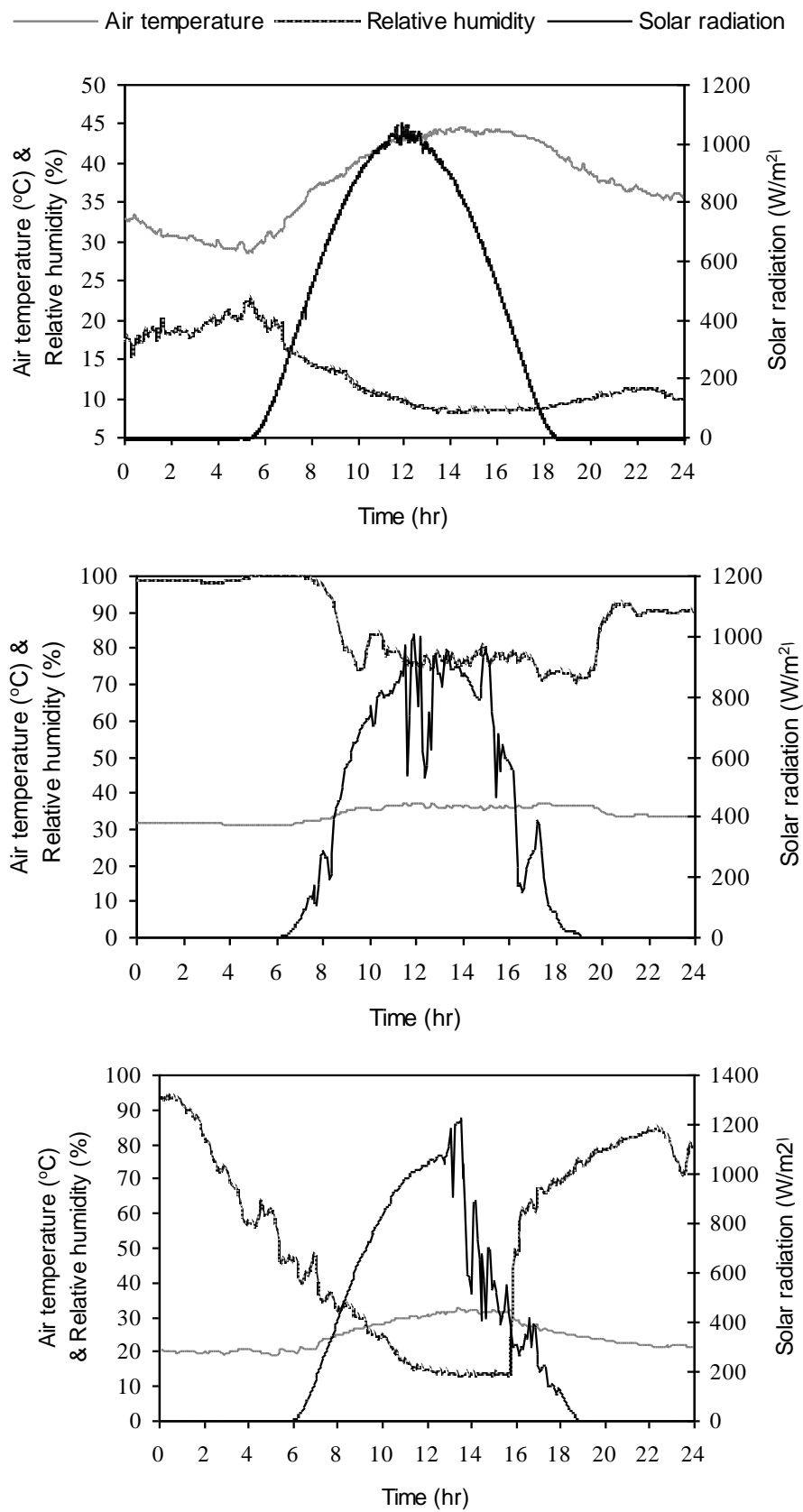

Figure 4. Hourly temperature $\left({ }^{\circ} \mathrm{C}\right)$, relative humidity $(\%)$ and solar radiation $\left(\mathrm{W} / \mathrm{m}^{2}\right)$ for Riyadh on August 4, 2001 (top), Jeddah on August 17, 2001 (middle) and Abha on July 17, 2001 (bottom). 
Table 2. Averages of temperature (T), relative humidity $(\mathrm{RH})$ and humidity ratio (W) for the air entering (in) and leaving (out) the cooler, cooling efficiency $(\eta)$, temperature drop (D) and the cooling power (q).

\begin{tabular}{|c|c|c|c|c|c|c|c|c|c|}
\hline \multirow[t]{2}{*}{$\begin{array}{c}\text { Climatic } \\
\text { conditions }\end{array}$} & \multicolumn{3}{|c|}{$\begin{array}{l}\text { Air entering the } \\
\text { cooler }\end{array}$} & \multicolumn{3}{|c|}{ Air leaving the cooler } & \multirow[t]{2}{*}{$\eta(\%)$} & \multirow[t]{2}{*}{$\mathrm{D}\left({ }^{\circ} \mathrm{C}\right)$} & \multirow{2}{*}{$q(W)$} \\
\hline & $\mathrm{T}_{\text {in }}$ & $\mathrm{RH}_{\text {in }}$ & $\mathrm{W}_{\text {in }}$ & $\overline{T_{\text {out }}}$ & $\mathrm{RH}_{\text {out }}$ & $\mathrm{W}_{\text {out }}$ & & & \\
\hline \multirow{7}{*}{ Arid } & 30.5 & 16 & 0.00432 & 18 & 70 & 0.00900 & 77 & 12.5 & 14595 \\
\hline & 35.4 & 11 & 0.00391 & 20.1 & 63.1 & 0.00925 & 80.5 & 15.3 & 17581 \\
\hline & 40 & 9 & 0.00411 & 22 & 59.4 & 0.00980 & 82.2 & 18 & 20379 \\
\hline & 40 & 12 & 0.00549 & 22.6 & 66.4 & 0.01139 & 84 & 17.4 & 19700 \\
\hline & 45 & 12 & 0.00715 & 24.5 & 69 & 0.01331 & 87 & 20.5 & 22845 \\
\hline & 45 & 7.6 & 0.00451 & 24 & 59 & 0.01100 & 84.3 & 21 & 23402 \\
\hline & 50 & 8.5 & 0.00651 & 26.5 & 65.4 & 0.01422 & 82 & 23.5 & 25783 \\
\hline Average & 40.8 & 10.9 & 0.00514 & 22.5 & 64.6 & 0.01114 & 82.4 & 18.2 & 20612 \\
\hline \multirow{7}{*}{ Humid } & 30 & 42 & 0.01114 & 23.2 & 70 & 0.01247 & 71.6 & 6.8 & 8033 \\
\hline & 31 & 67 & 0.01906 & 27.6 & 86 & 0.02014 & 67 & 3.4 & 3887 \\
\hline & 30 & 71 & 0.01907 & 27.2 & 88 & 0.02013 & 65 & 2.8 & 3308 \\
\hline & 35 & 58 & 0.02070 & 30 & 85 & 0.02297 & 68 & 5 & 5063 \\
\hline & 38.8 & 46.2 & 0.02028 & 31 & 83 & 0.02378 & 75 & 7.8 & 7125 \\
\hline & 40 & 45 & 0.02109 & 31.4 & 83 & 0.02435 & 74.5 & 8.6 & 7620 \\
\hline & 40 & 56 & 0.02646 & 32.2 & 88 & 0.02713 & 84 & 7.8 & 6911 \\
\hline Average & 35 & 55 & 0.01969 & 28.9 & $\begin{array}{l}83.3 \\
\end{array}$ & $\mathbf{0 . 0 2 1 5 7}$ & 72.2 & 6 & $\overline{5992}$ \\
\hline \multirow{6}{*}{ Moderate } & 28 & 19 & 0.00444 & 17 & 71 & 0.00856 & 80 & 11 & 13923 \\
\hline & 29 & 43 & 0.01076 & 23 & 70 & 0.01232 & 63 & 6 & 7332 \\
\hline & 30.5 & 16 & 0.00432 & 18 & 70 & 0.00900 & 77 & 12 & 14525 \\
\hline & 30 & 25 & 0.00659 & 19.7 & 74 & 0.01061 & 78 & 10.3 & 12168 \\
\hline & 30 & 42 & 0.01114 & 23.2 & 70 & 0.01247 & 71.6 & 6.8 & 8033 \\
\hline & 35.4 & 11 & 0.00391 & 20.1 & 63.1 & 0.00925 & 80.5 & 15.3 & 15317 \\
\hline Average & $\begin{array}{l}30.5 \\
30\end{array}$ & 26 & 0.00686 & 20.2 & $\begin{array}{l}69.7 \\
\end{array}$ & $\mathbf{0 . 0 1 0 3 7}$ & 75 & 10.2 & 11883 \\
\hline
\end{tabular}

For example, air at the inlet with temperature and relative humidity of $45^{\circ} \mathrm{C}$ and $7.6 \%$, respectively, was cooled to $24^{\circ} \mathrm{C}$, while the relative humidity increased to $59 \%$. The lowest temperature reduction was achieved at operating humid conditions with a value range of $2.8-8.6^{\circ} \mathrm{C}$ $\left(D_{\text {avg. }}=6^{\circ} \mathrm{C}\right)$. For example, air temperature was reduced from $40^{\circ} \mathrm{C}$ to $31.4^{\circ}$, while the relative humidity increased from $45 \%$ to $83 \%$ as a result 
of the evaporative cooling. Under operating moderate conditions, temperature reduction range was $6-15.3^{\circ} \mathrm{C}\left(\mathrm{D}_{\text {avg }}=10.2^{\circ} \mathrm{C}\right)$. The averages of air temperature at outlet were $20.2,22.5$ and $28.9^{\circ} \mathrm{C}$ under operating moderate, arid and humid conditions, respectively. On average, a maximum cooling power (cooling performance) of 20612W was obtained for the arid climatic conditions compared to $11883 \mathrm{~W}$ and $5992 \mathrm{~W}$ for moderate and humid climatic conditions, respectively.

Figure 5 shows water consumption during evaporative cooling $(1 / \mathrm{h})$ as a function of air speed at air temperatures of $35^{\circ} \mathrm{C}, 40^{\circ} \mathrm{C}$ and $45^{\circ} \mathrm{C}$ and relative humidity of $8 \%$ for the inlet air. The figure indicates that the highest amount of water consumption was $23.5 \mathrm{l} / \mathrm{hr}$ at air temperature of $45^{\circ} \mathrm{C}$ and air speed of $1 \mathrm{~m} / \mathrm{s}$, while the lowest $(7.3 \mathrm{l} / \mathrm{h})$ was obtained at operating air temperature of $35^{\circ} \mathrm{C}$ and air speed of $0.25 \mathrm{~m} / \mathrm{s}$. Cooling water consumption was found to be influenced by air temperature at the inlet. The average consumption of water at air temperature of $40^{\circ} \mathrm{C}$ and air speed of $0.5 \mathrm{~m} / \mathrm{s}$ was $11.8 \mathrm{l} / \mathrm{hr}$, whereas, at air temperature of $45^{\circ} \mathrm{C}$ the consumption increased to $13.8 \mathrm{l} / \mathrm{h}$. Figure also shows that cooling water consumption was increased by increasing air speed. For example, the consumption increased from $8.8 \mathrm{l} / \mathrm{hr}$ to $19.8 \mathrm{l} / \mathrm{hr}$ by increasing the air speed from $0.25 \mathrm{~m} / \mathrm{s}$ to $1 \mathrm{~m} / \mathrm{s}$ at air temperature of $40^{\circ} \mathrm{C}$.

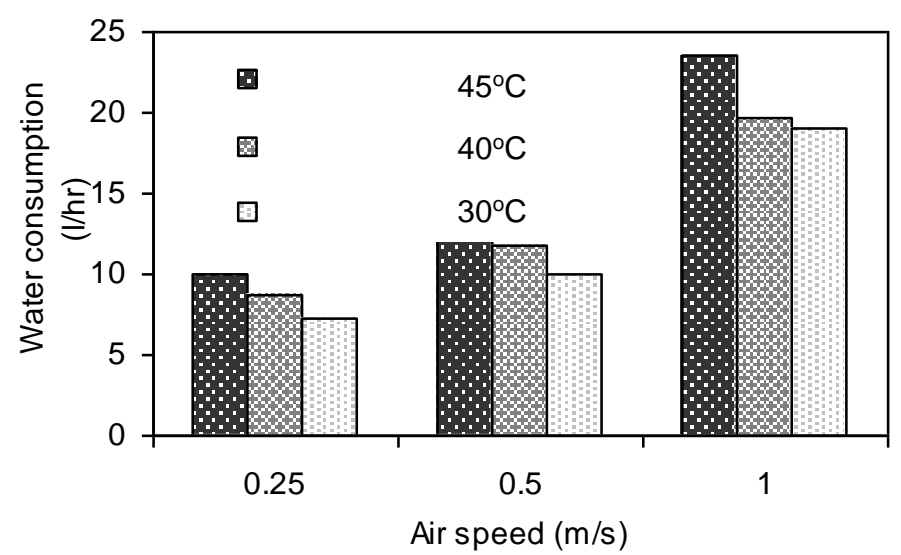

Figure 5. Water consumption rate during evaporative cooling $(1 / \mathrm{h})$ as a function of air speed at air temperatures of $35^{\circ} \mathrm{C}, 40^{\circ} \mathrm{C}$ and $45^{\circ} \mathrm{C}$ and relative humidity of $8 \%$ for the inlet air. 
The effect of temperature and relative humidity for the air at inlet on water consumption for cooling at different values of air temperatures and relative humidity is shown on figure. The figure shows that, at the same air temperature, the rate of water consumption increased as the relative humidity for the inlet air decreased. At air temperature and relative humidity of $35^{\circ} \mathrm{C}$ and $8 \%$, respectively, the water consumption rate was $13.8 \mathrm{l} / \mathrm{h}$. When the relative humidity increased to $58 \%$ at the same air temperature, the rate of water consumption decreased by $58 \%$ (to $5.8 \mathrm{l} / \mathrm{h}$ ).

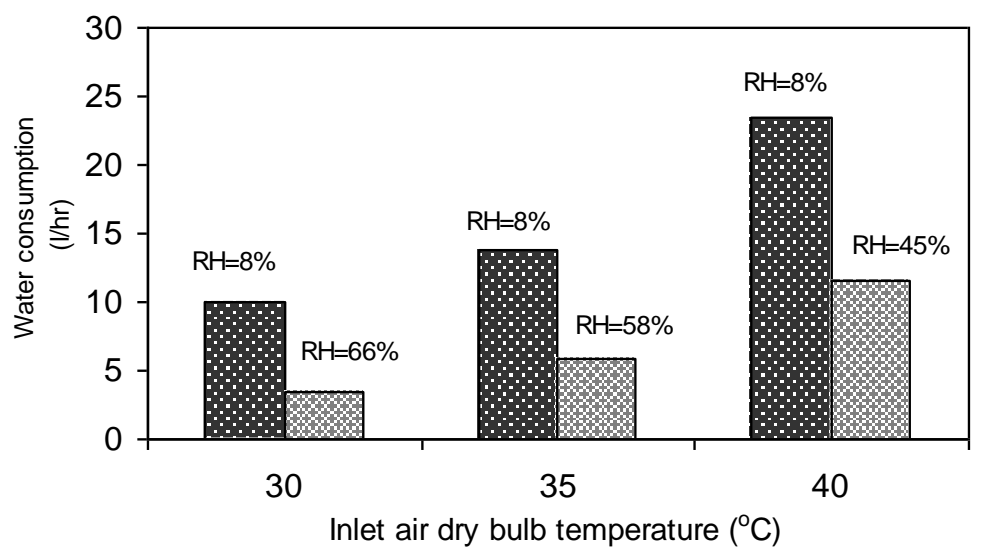

Figure 6. Water consumption rate during evaporative cooling $(1 / \mathrm{h})$ as a function of air temperatures and relative humidity for the inlet air.

\section{CONCLUSIONS}

The performance of a fan-pad evaporative cooling system has been investigated under a variety of climatic conditions. A test setup was designed particularly for small-scale evaporative cooling-process experiment. Weather data for Riyadh representing arid climate, Jeddah representing humid climate and Abha representing moderate climate were analyzed. The data was used for defining weather characteristics during summer, deciding the need for cooling of agricultural structures and determining the time of the day where the cooling load can reach its maximum level (peak). These data contained hourly readings for air temperature, relative humidity and solar radiation. Data showed that evaporative coolers are very effective under Riyadh conditions. In Jeddah, 
however, the hot air associated with high relative humidity lowers effectiveness of evaporative cooling. In Abha, climatic is more temperate during summer; conditions are more favorable for crop and animal production. The cooling efficiencies averaged at $82.4 \%$ under operating arid conditions, at $72.2 \%$ under humid conditions and at $75 \%$ under moderate conditions. Reductions in air temperature were $18.2^{\circ} \mathrm{C}, 6^{\circ} \mathrm{C}$ and $10.2^{\circ} \mathrm{C}$ under arid humid and moderate conditions, respectively. The highest amount of water consumption was $23.5 \mathrm{l} / \mathrm{hr}$ at air temperature of $45^{\circ} \mathrm{C}$ and air speed of $1 \mathrm{~m} / \mathrm{s}$, while the lowest $(7.3 \mathrm{l} / \mathrm{hr})$ was obtained at operating air temperature of $35^{\circ} \mathrm{C}$ and air speed of $0.25 \mathrm{~m} / \mathrm{s}$. Cooling water consumption was found to be influenced by air temperature at the inlet. The average consumption of water at air temperature of $40^{\circ} \mathrm{C}$ and air speed of $0.5 \mathrm{~m} / \mathrm{s}$ was $11.8 \mathrm{l} / \mathrm{hr}$, whereas, at air temperature of $45^{\circ} \mathrm{C}$ the consumption increased to $13.8 \mathrm{l} / \mathrm{hr}$. Also, cooling water consumption was increased by increasing air speed. At the same air temperature, the rate of water consumption increased as the relative humidity for the inlet air decreased. At air temperature and relative humidity of $35^{\circ} \mathrm{C}$ and $8 \%$, respectively, the water consumption rate was $13.8 \mathrm{l} / \mathrm{hr}$. When the relative humidity increased to $58 \%$ at the same air temperature, the rate of water consumption decreased by $58 \%$ (to $5.8 \mathrm{l} / \mathrm{hr}$ ).

\section{ACKBOWLEDGMENT}

Financial support for the research was provided by King Abdulaziz City for Science and Technology (KACST) through project no. AT-21-32, and the Research Center of the College of Food and Agricultural Sciences through project no. $31 \mathrm{HZR}$.

\section{REFERENCES}

Al-Helal, I. M. and H. S. Al- Towejeri. 2001. Evaporative cooling for Palm Dates Fiber Pads and Cross-Flutted Cellulose Pads under Arid Conditions. Misr Journal of Agricultural Engineering, Vol. 18 No. (2): 469-483.

Al-Helal, I. M., N. Al-Abbadi, and A. Al-Ibrahim. 2004. A study of fanpad performance for a photovoltaic powered greenhouse in Saud 
Arabian summer. International Agricultural Engineering Journal 13 (4): 113-124.

Ali A. K. A., A. A. Al-Haidary, and M. A. Alshaikh. 1999. The effect of evaporative cooling in alleviating seasonal differences in milk production of Almarai dairy farms in the Kingdom of Saudi Arabia. Asia Austral. Journal of Animal. 12 (4): 590-6.

Alodan, M. A. and A. A. Al-Faraj. 2005. Design and Evaluation of Galvanized Metal Sheets as Evaporative Cooling Pads. J. King Saud Univ. 18: 9-18.

Al-Sulaiman, F. 2002. Evaluation of the performance of local fibers in evaporative cooling. Energy Conversion and Management. (43): 2267-2273.

Arbel A, O. Yekutieli, and M. Barak. 1999. Performance of a fog system for cooling greenhouses. Journal of Agricultural Engineering Research. 72 (2):129-36.

ASAE. 2000. American Society of Agricultural Engineers. ASAE Engineering Practice 406.2, p.559-566. ASAE Standards. ASAE, St. Joseph, MI. 49085.

Bottcher, R. W., G. R. Baughman, R. S. Gates, and M. B. Timmons. 1991. Characterizing efficiency of misting systems for poultry. Transactions of the ASAE. 34(2): 586-590.

Bucklin, R., L. Turner, D. K. Bray and R. W. Hemken. 1991. Method to relieve heat stress for dairy cows in hot, humid climates. Applied engineering in Agriculture. 7 (2): 241-247.

Chen C. 2003. Prediction of longitudinal variations in temperature and relative humidity for evaporative cooling greenhouses. Agricultural engineering journal. 12 (3\&4): 143-164.

Deaton, J. W., J. L. McNaughton, and B. D. Lott. 1982. Effect of heat stress on laying hens acclimated to cyclic versus constant temperatures. Poultry science. 61(5):875-878.

El-Nouty, F. D.; A. A. Al-Haidary; and M. S. Salah. 1990. Spray cooling effects on milk production; some blood parameters and thyroid hormones of Holstein cows in the semi-arid environment. Indian $\mathbf{J}$ Anim Sci. 63: 360-364. 
Gates, R. S., J. L. Usry, and J. A. Nienaber. 1991. An optimal misting method for cooling livestock housing. Transactions of ASAE. 34 (5):2199-206.

Helsen, A. and J.Willmot. 1991. Wet air cooling of fruits, vegetables and flowers. Current practice in Europe. Technical innovation in freezing and refrigeration of fruits and vegetables. Paris, France: International Institute of Refrigeration. p. 169-77.

Jain, D. and G. Tiwari. 2002. Modeling and optimal design of evaporative cooling system in controlled environment greenhouse. Energy Conversion and Management. 43: (2235-2250).

Kittas, C., T. Bartzana and A. Jaffrin. 2001. Greenhouse evaporative cooling: measurement and data analysis. Transactions of the ASAE. 44(3): 683-689.

Lieo. C. and K. Chiu. 2002. Wind tunnel modeling the system performance of alternative evaporative cooling pads in Taiwan region. Building and environment 37: 177-187.

Montero, J. I.; T. H. Short; R . B. Curry and W. L. Bauerle. 1981. The influence of various water evaporation systems in the greenhouse environment. ASAE paper No. 81-4027.

Reece, F. N., J. W. Deaton, and L. F. Kubena. 1972. Effects of high temperature and humidity on heat prostration of broiler chickens. Poultry science. 51(2): 2021-2025.

Ryan, D. P., M. P. Boland and E. Kopel. 1992. Evaluating two different evaporative cooling management systems for dairy cows in hot, dry climate. Journal of Dairy Science. 75 (4):1052-9.

Umbarker S.P., R.S. Bonde, M.N. Kalase. 1991. Evaporatively cooled storage stature for oranges (citrus). Indian Journal of Agricultural Engineering. 1(1): 26-32.

Watt, J. R. 1953. Investigation Evaporative Cooling. Report U.S. Naval civil Engineering Research and Evaluation Laboratory.

Wiersma, F. and D. S. Benham, 1974. Design criteria for evaporative cooling. ASAE Paper No. 74-4527, ASAE, St. Joseph.MI 49085.

Zabeltitz, C. V. 2002. Ventilation and cooling of Greenhouses in Hot Arid Climate Presented at Second Protected Agriculture Regional Technical Coordination Meeting, Kuwait. 


\section{الملخص العربي}

\section{دراسة معملية لأداء المبرد التبخيري بالمراوح والوسائد تحت ظروف مناخية مختلفة بالمملكة العربية السعودية والوبية}

\section{إبراهيم بن محمد الههلا}

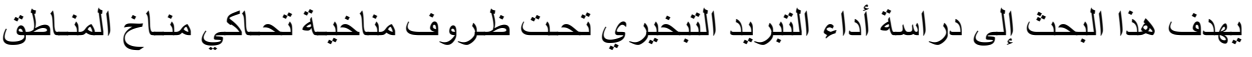

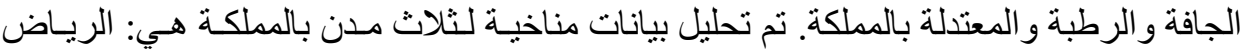

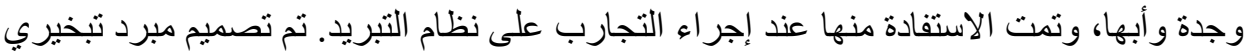

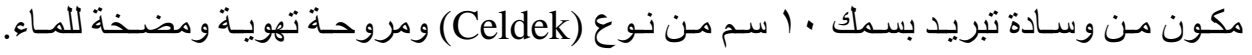

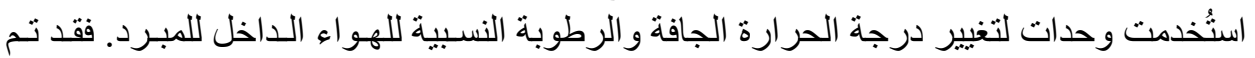

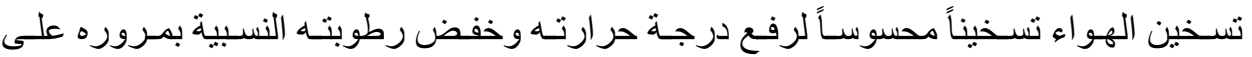

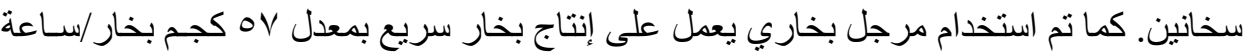
تحت ضغط 0,0 بار لترطيب وتسخين الهو اء. رُكبت كل وحدة من الوحدات (التبريد و التسـخين

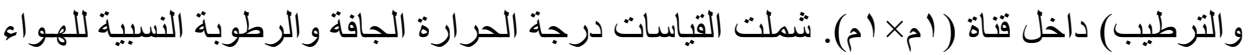

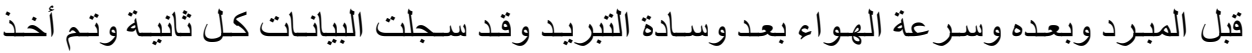

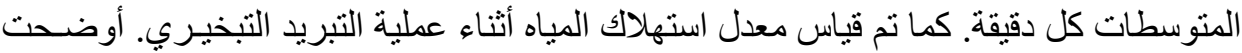

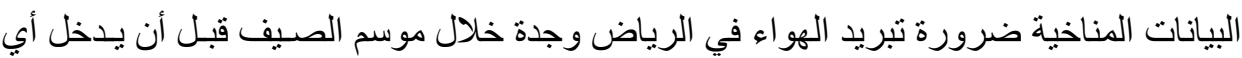

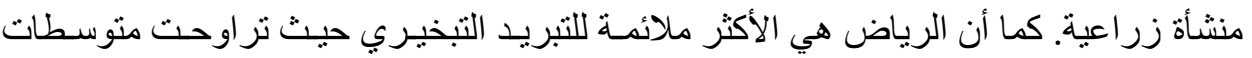

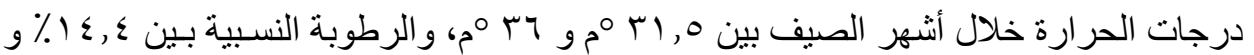

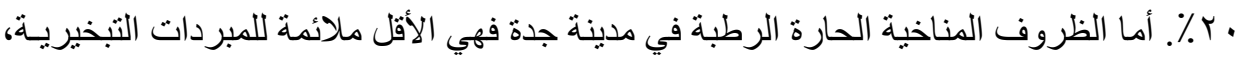

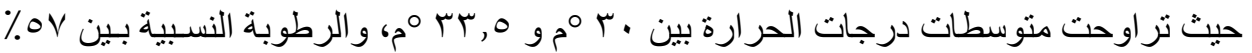

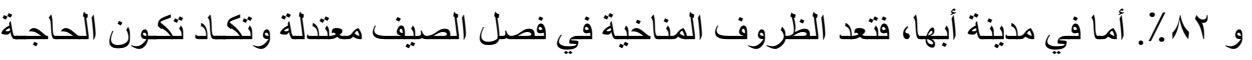
للتبريد معدومة. قد يستنتى من ذللك البيوت المحمية التي ترتفع فيها درجة الحـر ارة بسـبـ فيب تجميع

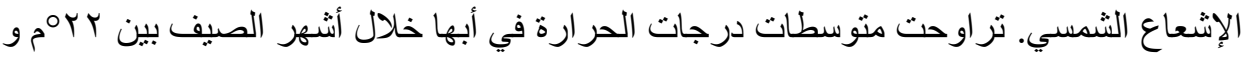

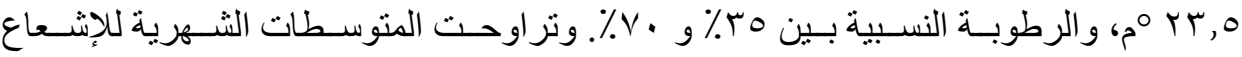

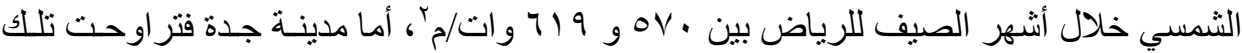

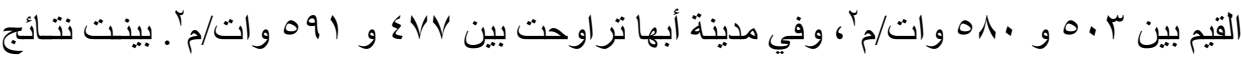

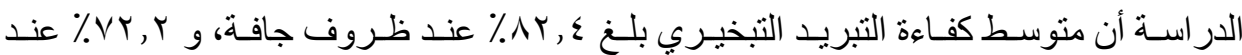

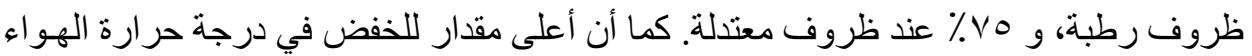

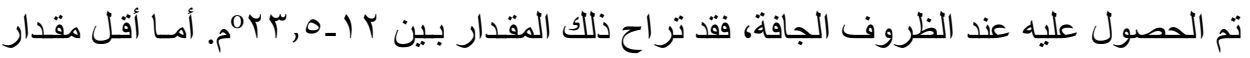

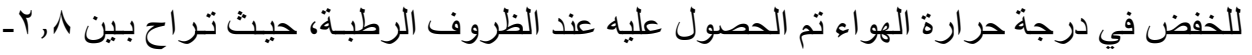

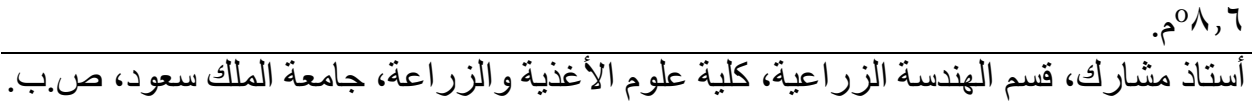
. 


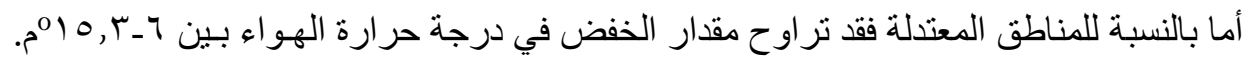

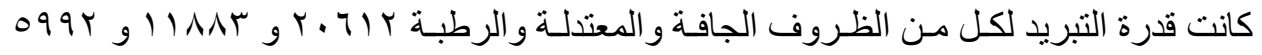

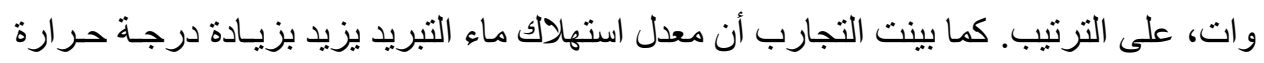

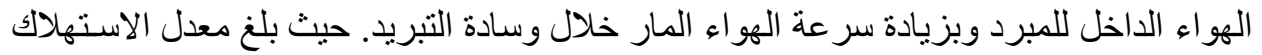

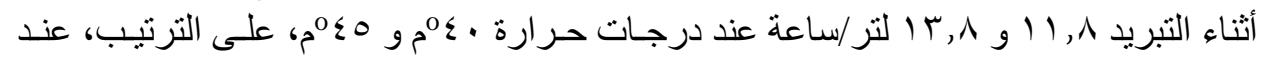

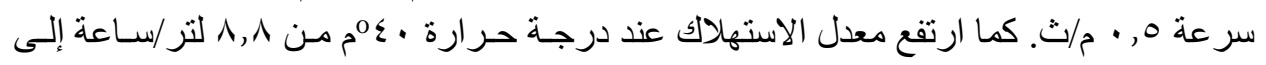

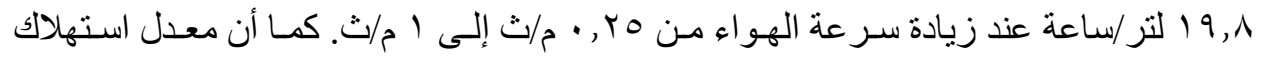

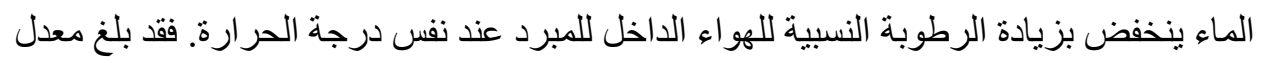

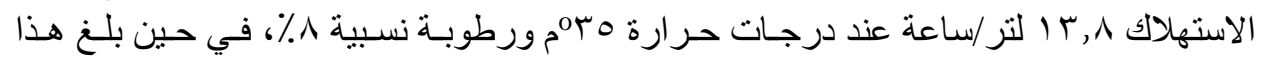

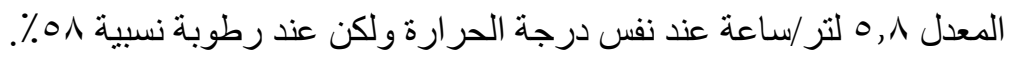

